\title{
PERFORMANCE CHANGES \\ OF THE TOURISM SECTOR IN THE CRISES
}

\author{
Grozdana Marinković ${ }^{1}$ (i) \\ Slavica Stevanović ${ }^{2}$ (D)
}

DOI: https://doi.org/10.31410/tmt.2020.425

\begin{abstract}
Tourism represents a driver of economic growth and job creation all around the world. It has become one of the key factors of progress, not only of the individual destinations and regions but also the world economy. The paper aims to analyze the effects of different types of the crisis on the volume of tourism activities, tourism turnover, and revenues in the tourism sector. Despite occasional crisis situations and shocks, tourism has seen continued expansion and has shown great resilience. Having in mind that the COVID-19 pandemic has a major impact across world regions, as well as tourism is one the hardest-hit sectors, a special part of the paper analyzes the impact of the health crisis in Serbia and the global level. The intensive and deep impact of the pandemic on the tourism sector requires strong support at the national and global levels through the relevant institutions.
\end{abstract}

Keywords: Tourism sector, Crisis, COVID-19, Global level, Serbia, Supporting measures.

\section{INTRODUCTION}

$\mathrm{T}^{-1}$

ourism belongs to a group of social systems that represent a specific combination of natural, technical, social, and economic elements/subsystems (Popesku, 2016, p. 24). The basic characteristics of tourism are variety, non-productive and seasonal character of the business, a high degree of elasticity of demand and supply inelasticity. Tourism has continued growth and is declared as one of the key development factors of the individual tourist destinations and countries, as well as the global economy. The reason for that is the favorable economic progress in the world, the increase in leisure and living standards.

Over the past six decades, tourism becomes one of the fastest-growing economic sectors in the world. The tourism sector has multiplier effects on the development of local destinations, individual countries, and regions, as well as the development of complementary activities (Ministry of Trade, Tourism and Telecommunications, 2016). The global spread of tourism in developed countries has produces different benefits in many related sectors.

Tourism represents a significant economic phenomenon that is in the constant and strong changes process. Despite occasional shocks, international tourist arrivals have shown continuous growth. The sector recorded 25.3 million participants in international tourism and 2 billion US\$ of revenues from tourism activities (Popesku, 2016, p. 3). Thirty years later, international tourist arrivals amounted to 277 million, in 1990 to 438 million, while in 2000 there were 680 million participants in international tourism (World Tourism Organization, 2011). An average annual growth rate of international tourism arrivals in the period 2010-2018 was 5\% (World Tourism Organization, 2019).

\footnotetext{
$1 \quad$ Belgrade Banking Academy, Faculty for Banking, Insurance and Finance, Zmaj Jovina 12, Belgrade, Serbia

2 Institute of Economic Sciences, Zmaj Jovina 12, Belgrade, Serbia
} 
Improving the quality and flexibility of the institutional framework is a precondition for improving competitiveness, increasing efficiency, and productivity of the economy as well as economic sectors (Stevanović \& Jovičić, 2016, p. 375). Over time, tourism has grown into a global phenomenon with a strong role in overall economic and social development. Tourism generated US\$ 1.5 trillion receipts in destinations and US\$ 256 billion in passenger transport, which was US\$ 1.7 trillion exports from international tourism in 2018 (World Tourism Organization, 2019). 2019 was another year of intensive growth for the global tourism sector. Approximately, 1,460 million international tourist arrivals and international tourism receipts in the amount of US\$ 1,482 billion were recorded in 2019 (World Tourism Organization, 2020a). The contribution of travel and tourism to the global economy GDP amounted to $10.3 \%$ in 2019, which was US\$ 9.8 trillion. About 330 million jobs or every tenth job belongs to the travel and tourism sector (World Travel \& Tourism Council, 2020a).

Growth in international tourism arrivals and receipts continues to outpace the world economy. According to the data of the World Tourism Organization, travel and tourism GDP grew at the rate of $3.9 \%$ in 2018 outpacing the global economy for the eighth consecutive year - overall economy GDP growth was 3.2\% (World Travel \& Tourism Council, 2019). While the global economy GDP grew by $2.5 \%$, tourism and travel grew significantly more at $3.5 \%$ in 2019 (World Travel \& Tourism Council, 2020a).

According to estimates in the publication Tourism Towards 2030 that covers the period 20102030, the number of international tourist arrivals will grow by an average rate of $3.3 \%$ (World Tourism Organization, 2016). However, tourism is strongly affected by the health crisis in 2020 that has caused major changes in social and economic activities, such as the problems in global trade, reduction of global GDP, border closures, as well as a sharp decline in tourism activities and sector's revenues.

This paper aims to analyze the effects of the current crisis and crises from the earlier period on the financial performances in the tourism sector. Our analysis includes desk research, and it is focused on the tourism sector on the global and national levels. The research is based on secondary data from international and national publications. This paper includes an introduction, four sections, future research directions and a conclusion. The overview of crisis situations in the tourism sector is presented in the first section, the impact of the COVID-19 pandemic on global tourism in the second, the state and perspectives of the Serbian tourism sector in the third, and fourth section contains measures for supporting tourism recovery.

\section{CRISIS SITUATIONS IN TOURISM SECTOR}

Tourism is constantly facing crisis situations in the conditions of global tourist activities. Crisis in tourism can be defined as unexpected events that reduce the confidence of travelers in the destinations and disable the normal conduct of tourist activities. The existence of the crisis increases the risk, uncertainty, fear of travel and concern for safety that affects the reduction of tourist services demand. Each crisis leads to a slowdown or decline in tourism incomes and imposes the need for swift and adequate measures that will enable the normal conduct of activities, safety and satisfaction of tourists.

At the beginning of the $21^{\text {st }}$ century, a more intensive study of the impact of the crises on the sector is noticeable as a direct consequence of the events that affected tourism turnover and 
revenues. There are various types of crises and all of them have more or less negative implications on the tourism sector. The basic factors that can cause a crisis in the tourism sector are the economic, political, environmental factors, socio-economic, technical-technological factors, etc. (Popesku, 2016, p. 256). Table 1 provides an overview of the key factors that can cause crisis situations in the tourism sector.

Table 1. Key factors of the crises in tourism

\begin{tabular}{|l|l|l|}
\hline \multicolumn{3}{|c|}{ Factors/Causes of the crises in tourism } \\
\hline \multicolumn{1}{|c|}{ Economic factors } & \multicolumn{1}{|c|}{ Political factors } & \multicolumn{1}{c|}{ Environmental factors } \\
\hline Financial crises & Instability & Natural disasters \\
Recession & Terrorism & Climate changes \\
& Anarchy & Environmental pollution \\
& Coups & \\
\hline
\end{tabular}

Source: Authors adopted from Popesku, 2016.

The political factors lead to instability, uncertainty and reduced attractiveness of a certain tourist destination. Anarchy, coups, wars, strikes are some of the examples that cause political instability, tourist insecurity and concern for personal safety. The first two decades of the $21^{\text {st }}$-century record examples of terrorist attacks that have increased fear and insecurity among tourists, which directly implies a decrease in the number of international tourist arrivals and income of the sector.

The global economic crisis belongs to a group of economic factors. The long-lasting economic crisis as well as the process of globalization, turbulent technological, and economic changes, has had a significant impact on the world economy. To overcome the consequences of the crisis and ensure economic growth and prosperity in the long term, states must choose appropriate strategies that would lead to the successful goals' achievement (Baranenko \& Stevanović, 2013, p. 420).

Although the crisis started in 2008, intensive and strong impacts of the crisis on the tourism sector were noticed in 2009. Figure 1 shows the percentage changes in the number of participants in the international travel that refer to 2009/2008 and 2010/2009, i.e. in the years after the first impact of the world economic crisis. World tourism recorded 3.8\% fewer tourists compared to 2008. Under the impact of the global financial crisis and the following economic recession, the number of international tourists declined in 2009 to 880 million (World Tourism Organization, 2011).

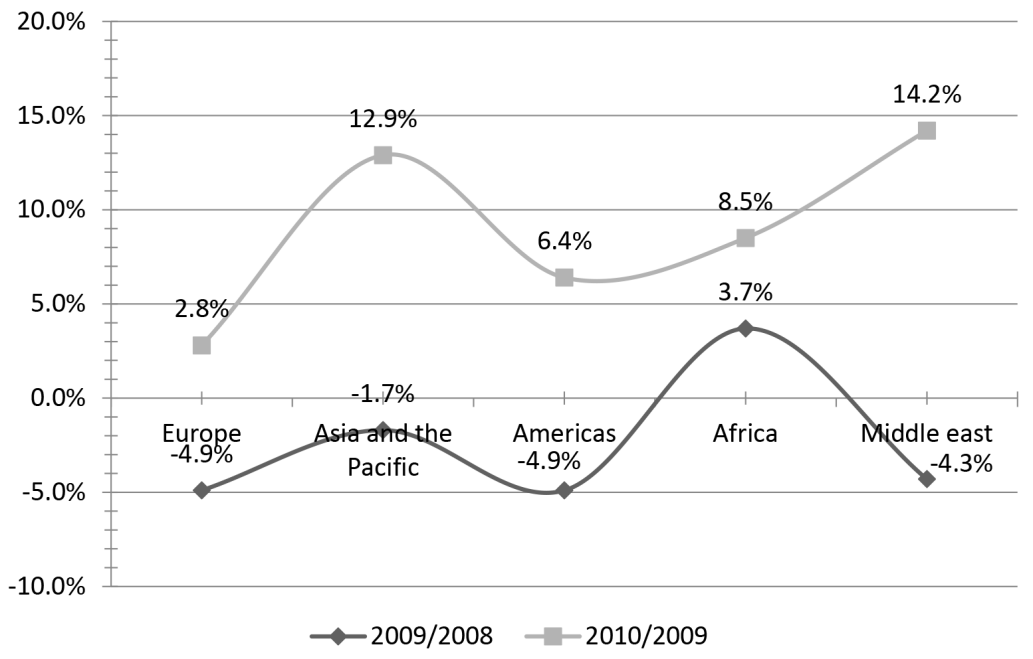

Figure 1. Percentage changes of international arrivals after the crisis in 2008

Source: Authors based on World Tourism Organization data, 2011 and 2012 
Observed by tourist regions, the largest decrease in tourist arrivals was realized in Europe and America (both $-4.9 \%$ ), followed by the countries of the Middle East (-4.3\%). Only Africa recorded a positive trend and a positive growth rate of $3.7 \%$ compared to 2008 . The global crisis left significant negative consequences in various sectors in most national economies. However, international tourism rebounded strongly, and already in 2010, all tourist regions recorded an increase in the number of foreign tourists. International tourist arrivals raised $6.6 \%$ over 2009, to 940 million (World Tourism Organization, 2012). The highest growth was noticed in the Middle East, as well as in Asia and the Pacific (14.2\% and 12.9\%, respectively).

Many new tourism destinations have emerged alongside the traditional ones of Europe and North America. However, Europe was the most attractive region with a share in global tourism over $50 \%$, while all other destinations had participation slightly less than $50 \%$. Although tourism in Europe grew by 2.8\% (from 461.7 million tourists in 2009 to 474.8 million in 2010), it did not reach the level from 2008 when 485.2 million international were registered. Table 2 shows realized receipts from international tourism in the period 2008-2010.

Table 2. International tourism receipts in the period 2008-2010 (in US\$ billion)

\begin{tabular}{|c|c|c|c|c|c|}
\hline \multirow[b]{2}{*}{ Year } & \multicolumn{5}{|c|}{ Tourist region } \\
\hline & Europe & $\begin{array}{l}\text { Asia and } \\
\text { the Pacific }\end{array}$ & Americas & Africa & Middle East \\
\hline 2008 & 473.7 & 208.9 & 188.1 & 30.2 & 39.7 \\
\hline 2009 & 410.9 & 203.1 & 166.2 & 28.8 & 42.0 \\
\hline 2010 & 409.3 & 255.3 & 180.7 & 30.4 & 51.7 \\
\hline
\end{tabular}

Source: Authors based on World Tourism Organization data, 2010, 2011, 2012

Compared to 2008 when the total international tourism receipts reached US\$ 940 billion, the decrease was recorded in 2009 (total receipts amounted to US\$ 851 billion). Observed by the regions, Europe noticed the largest share in the total receipts in all years, although the reduction is noticeable in 2010. After more than a year of negative results, it is noticed the growth in international tourism in the last quarter of 2009.

Environmental factors that can lead to crisis situations in tourism include natural disasters (earthquakes, floods, hurricanes, etc.), climate changes and environmental degradation caused by human activities such as carbon dioxide emissions into the atmosphere (Milićević \& Ervaćanin, 2016, p. 56). In addition to the above, it is important to emphasize the relevance of the health crisis for the tourism sector. The crises caused by H1N1 and SARS epidemic and the Ebola virus have affected the drop in the tourism sector, decrease in the number of travelers in the air traffic, reduction in tourism revenues in the affected destinations, as well as the decrease of incomes in the catering facilities.

\section{THE IMPACT OF THE COVID-19 PANDEMIC ON THE GLOBAL TOURISM}

Tourism has seen continued expansion and has shown great resilience despite occasional crisis situations and regardless of the factors that caused them. However, the health crisis caused by the COVID-19 pandemic abruptly interrupted the development of world tourism and led to a decrease in global sector activities and tourism revenues. The crisis has affected the enormous reduction in the number of foreign tourists, international tourist arrivals, overnight stays, and restaurant meals. The crisis as a result of the pandemic does not have an equal impact on all economic sectors. The countries hardest hit by the crisis are those that largely depend on tour- 
ism, transport and other economic activities that have been most affected by the measures of restriction of movement. The catering and tourism sectors face serious problems, with a very possible scenario in which restricting the movement of people continues to prevent sector recovery and creates strong pressure on employment (Marjanović \& Đukić, 2020, p. 102). The crisis can significantly affect seasonal workers who are generally employed abroad in the hospitality or service industry during peak times of tourism, and the unemployment rate could therefore rise even further (Pavlović et al., 2020, p. 7).

Data for the first eight months of 2020 indicate a decrease of $70 \%$ in the number of international tourist arrivals, while the reduction of $93 \%$ was recorded in June 2020 compared to the same period in 2019. Table 3 shows the total number of international tourist arrivals in the period 2017-2019, as well as the percentage changes over the same period of the previous years. Compared to 2017 when there were recorded about 1,332.4 million arrivals, the number of participants in international tourism in 2019 increased to 128 million arrivals or 9.6\% (World Tourism Organization, 2020a).

Table 3. International tourist arrivals and percentage changes

\begin{tabular}{|c|c|c|c|c|c|c|}
\hline \multirow[t]{2}{*}{ Tourist region } & \multicolumn{3}{|c|}{ In millions } & \multicolumn{3}{|c|}{$\begin{array}{c}\text { \% change over the same period } \\
\text { of the previous year }\end{array}$} \\
\hline & 2017 & 2018 & 2019 & $2018 / 2017$ & $2019 / 2018$ & $2020 / 2019$ \\
\hline Europe & 676.6 & 715.8 & 743.7 & $5.8 \%$ & $3.9 \%$ & $-67.7 \%$ \\
\hline Asia and the Pacific & 324.1 & 347.7 & 360.1 & $7.3 \%$ & $3.6 \%$ & $-78.8 \%$ \\
\hline Americas & 210.8 & 215.9 & 219.5 & $2.4 \%$ & $1.6 \%$ & $-64.8 \%$ \\
\hline Africa & 63.3 & 68.7 & 71.9 & $8.4 \%$ & $4.7 \%$ & $-69.1 \%$ \\
\hline Middle East & 57.6 & 60.1 & 65.1 & $4.3 \%$ & $8.3 \%$ & $-68.7 \%$ \\
\hline
\end{tabular}

Source: Authors adopted from World Tourism Organization data, 2020a

The dominant position in the distribution of international tourism is occupied by European destinations, followed by Asia and the Pacific, as well as America. The great number of international tourist arrivals was recorded in Europe in all years of analysis (over 50\%), followed by countries of Asia and the Pacific (on average about 24\%). Europe represents the largest world region in terms of international visitor spending. According to the data of the World Tourism Travel Council, US\$ 619 billion of international visitor spending was noticed in Europe in 2019, which is $37 \%$ of global international spending in 2019 (World Travel and Tourism Council, 2020a). The European countries that have the most contributed to GDP are Germany, Italy, the United Kingdom, France and Spain. Figure 2 shows percentage changes in international tourist arrivals in five tourism destinations. The percentage changes refer to 2019/2018 and 2020/2019. The percentage change in 2020/2019 refers to the change in the period January - August 2020 compared to the same period of the previous year.

An enormous decrease in tourist activities was recorded in all tourist regions, which was a direct implication of the health crisis caused by a coronavirus. After a long series of years, the growing trend of international arrivals has been interrupted. International tourist arrivals decreased and ranged between 64 and 79\% compared to the same period in 2019. Regions, Asia, and the Pacific as the first region to suffer the impact of COVID19, recorded a $78.8 \%$ decrease in international tourist arrivals in the first eight months of 2020. It is the biggest drop of all analyzed regions. The second hardest-hit region was Africa with $-69.1 \%$, followed by the countries of the Middle East (-68.7\%). In Europe that is characterized as the most visited destination on the global level, there was a decrease of $67.6 \%$ compared to the period in 2019 (World Tourism Organization, 2020a). 


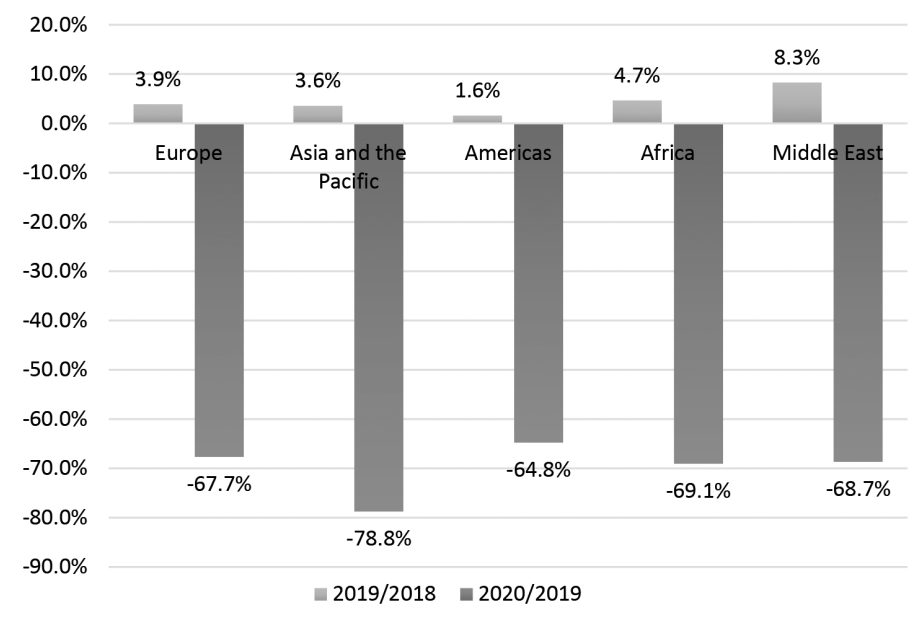

Figure 2. Percentage changes of international tourist arrivals

Source: Authors based World Tourism Organization data, 2020a

The movement restrictions and closing borders in a great number of countries around the world led to a steep reduction in international tourist receipts. Figure 3 shows the percentage of changes in participants in international tourism in the first and second quarters of 2020 relative to the same period of the previous year. Although the first quarter shows a decrease compared to 2019, the strong effects of the crisis were mostly reflected in the period April-June. All regions recorded a steep decline ranging from $-92.9 \%$ in America to $-98.9 \%$ in the Middle East and Africa (World Tourism Organization, 2020a).

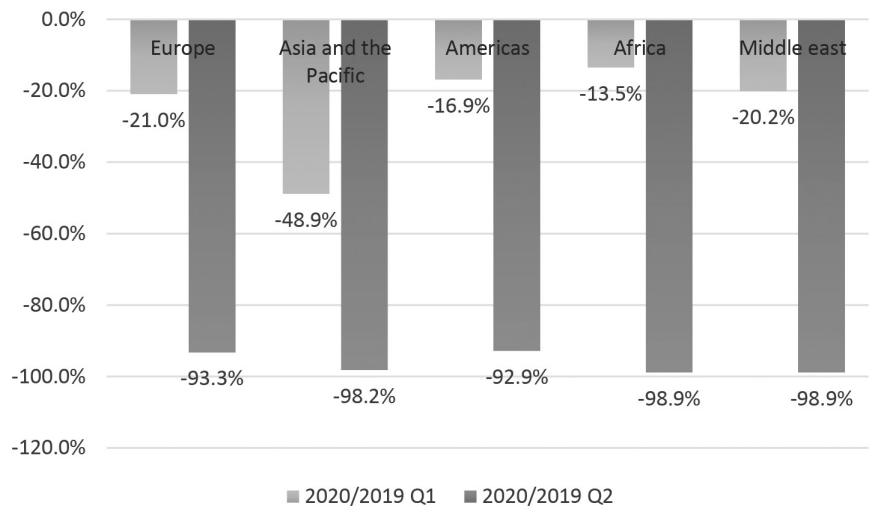

Figure 3. Percentage of quarterly changes of international tourist arrivals

Source: Authors based on World Tourism Organization data, 2020a

The latest data of the World Tourist Organization show that the massive drop in international travel demand over the period January-August of 2020 generated a loss of 770 million international arrivals compared to the same period in 2019, as well as about US\$ 730 billion in export revenues from international tourism. The losses due to the appearance of COVID-19 are more than eight times higher compared to the loss in tourism that occurred as a result of the global economic crisis of 2008 (World Tourism Organization, 2020a).

\section{THE STATE AND PERSPECTIVES OF TOURISM SECTOR IN SERBIA}

As in other parts of the world, Serbian tourism is not immune to crisis situations. The crisis period of the Serbian economy began in the early 1990s. Serious restrictions on the growth of economic activity since that period, which relate to war events, problematic international 
position, long transition process, financial difficulties, were accompanied by a decline in economic competitiveness and weakening of internal capacities of individual economic entities. Crisis situations result in a disruption of the financial structure of the national economy. The accumulated financial and structural problems of the Serbian economy are becoming even more pronounced after the world economic crisis (Stevanović, 2015, p. 347).

The global economic crisis has hit most economic areas, including tourism. Due to the reduced purchasing population power, the crisis has led to a decrease in the number of tourists and a drop in sector revenues. Although the beginning of the crisis is related to 2008, the strong effects of the global economic crisis were felt in 2009. The number of tourist arrivals decreased from 2,266 thousand in 2008 to 2,018 thousand participants in tourism in 2009 (Statistical Office of the Republic of Serbia, 2011). The number of domestic tourists decreased slightly, while the decline in tourist arrivals was predominantly caused by a decrease in international arrivals. 1,373 thousand international arrivals were recorded in 2009 that is $15 \%$ less than in the previous year. Although the crisis has affected various segments of economic activity, the tourism sector has shown significant resilience and recovered relatively quickly. Since 2011, the number of tourist arrivals has been gradually increased, with a significantly changed structure in terms of the number of foreign and domestic tourists.

The share of domestic tourists in the structure of total tourists' arrivals is gradually increasing in the period 2008-2019 (from 646 thousand in 2008 to 1,846 thousand arrivals in 2019). Figure 4 shows the number of tourist arrivals in the period 2008-2019.

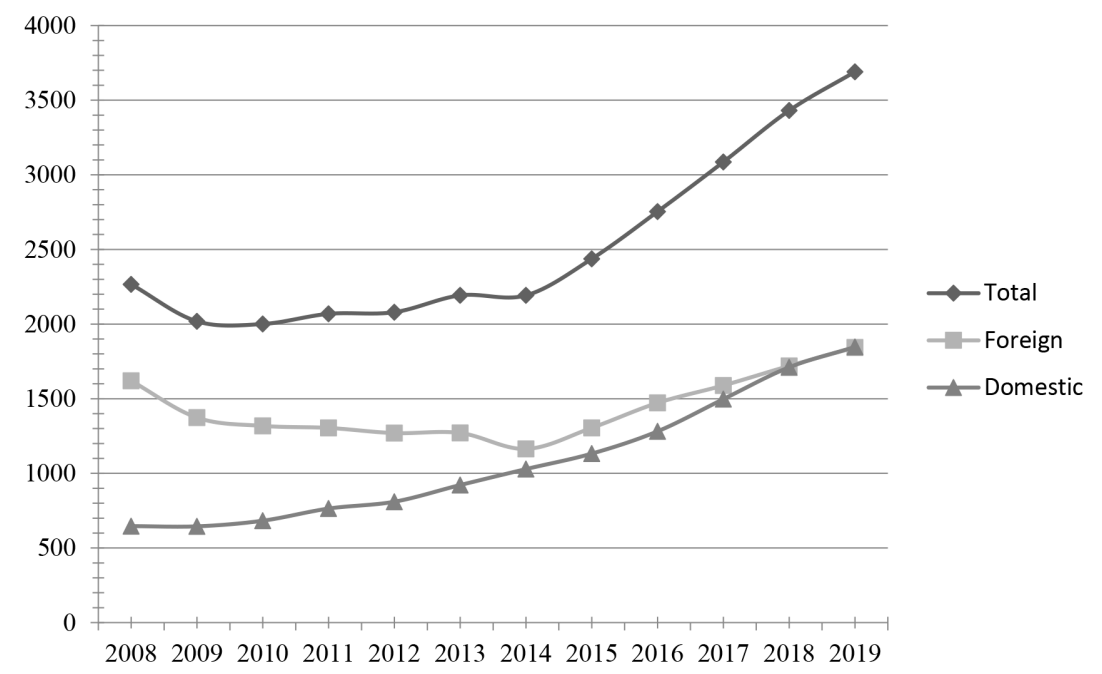

Figure 4. Tourist arrivals in period 2008-2019 (in 000)

Source: Authors based on Statistical Office of the Republic of Serbia data, 2020a

There were 4,010 thousand nights spent by foreign tourists in 2019 (an increase of $9.6 \%$ compared to the previous year), while the number of overnight stays of domestic tourists amounted to 6,063 thousand the night that was $6.8 \%$ higher than 2018 (Statistical Office of the Republic of Serbia, 2020a).

The tourism sector plays a significant role in the national economy by contributing to GDP, as well as to employment and jobs. According to the data of the World Travel and Tourism Council for 2019, the contribution of the travel and tourism sector to Serbian GDP was 5,9\%. The sector employs 134.8 thousand employees that represent about $6.2 \%$ of the total number of employees 
(World Travel and Tourism Council, 2020b). The data from macroeconomic announcements and the annual bulletin published by the Serbian Business Registers Agency - SBRA show that the largest part of gross domestic product was generated in non-tradable sectors, most in sector $\mathrm{G}$ - Wholesale and Retail trade, sector N - Transportation and storage and sector I - Accommodation and food service activities (SBRA, 2020).

According to the Regulation on Sector Classification, the sector named Accommodation and food service activities contains the providing of accommodation for shorter stays of visitors and other travelers, as well as the preparation of complete meals and drinks for direct consumption. This section of activities belongs to the sectors that record employment growth and increase in the number of business entities. The number of employees recorded an $8 \%$ increase in 2019 compared to the previous year (29,725 in 2018 and 32,191 employees in 2019), while the sector employs 9,571 people more in relation to 2015. The increase in the attractiveness of the sector is also visible through the enhancement of the number of business entities that perform the tourist activities - an increase from 3,204 in 2015 to 4,078 legal entities in 2019 (SBRA, 2017; 2020).

Publicly available publications, statistics, and registers provide insight into the achieved business and financial performances of individual entities, but also aggregate information for sectors and the whole economy (Marinković, 2019, p. 24). The total revenues in the Accommodation and food service activities sector are more than doubled compared to $2015(64,829,795$ thousand dinars in 2015 and 145,212,472 thousand dinars in 2019). Revenues growth was accompanied by expenditure growth. The total costs of the tourism sector increased in 2019 compared to 2015 by $113 \%$. Figure 5 shows an achieved net financial results in the period 2015-2019 (SBRA 2016; 2017; 2018; 2019; 2020).

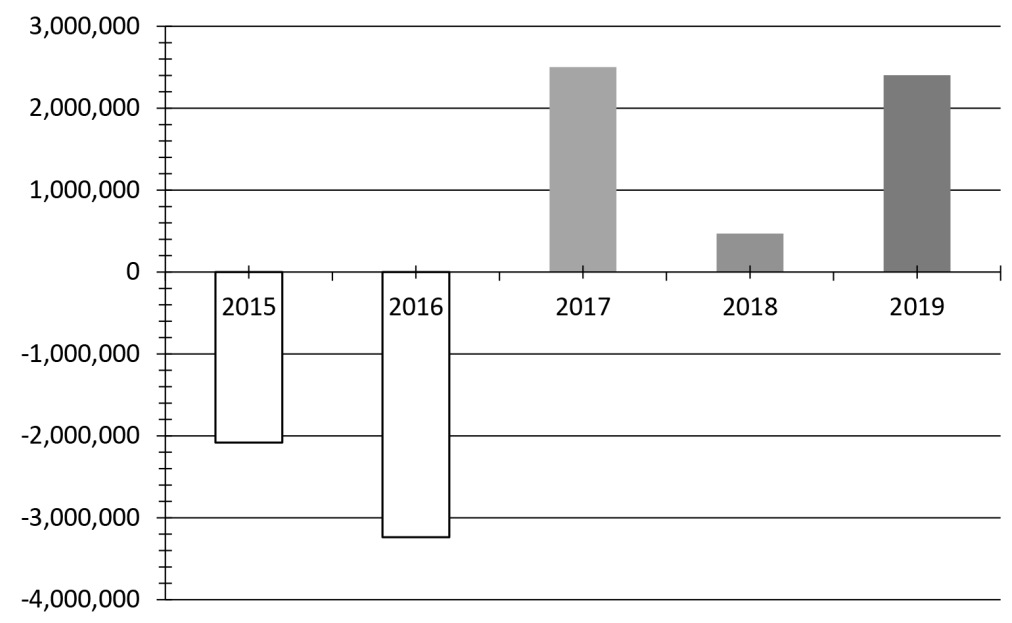

Figure 5. Net results in the sector Accommodation and food service activities (in 000 dinars)

Source: Authors based on SBRA data, 2016; 2017; 2018; 2019; 2020

The Accommodation and food service activities sector has shown negative net results for years. The tourism sector operated in the loss zone in 2015 and 2016 (2.0 billion dinars and 3.2 billion dinars, respectively), but achieved negative results are smaller compared with 2014 when the sector reported net negative financial results of 6.0 billion dinars (Marinković, 2018, p. 390). A series of negative financial performances were interrupted in 2017 when the sector recorded a net profit of 2.5 billion dinars. The trend of positive performances in the tourism sector continued in 2018 when the data from the aggregate income statement showed a net profit of 0.47 billion dinars, as well as in 2019 with 2.4 billion dinars (SBRA, 2020). 
Except for the previous public available statements and bulletins that represent a good basis for monitoring sector development, the Serbian Business Register Agency leads the Register of Tourism established in 2010, aiming to monitor, analyzing and developing tourism. The key register's activity is to provide the main information about registered entities in the tourism sector, the tourist agencies and the tour-operators (Tourism Law, 2018). Ivanović et al. (2020, p. 97) analyze the Tourist Organization of Serbia as the official carrier of the institutional promotion of Serbian tourism.

The Statistical Office of the Republic of Serbia keeps statistics on catering and tourism. This institution monitors the total number of foreign and domestic tourists, the number of foreign and domestic overnight stays, arrivals and overnight stays on month and annual level, arrivals and overnight stays by regions, countries of origin, accommodation capacities, the structure of tourist receipts, etc. Data are collected by the monthly statistical reports issued by catering trades and business entities providing accommodation services or mediating in tourist services. The methodology is based on the European Union and World Tourism Organization recommendations for tourism statistics (Statistical Office of the Republic of Serbia, 2020a).

According to the data of the World Travel and Tourism Council, international visitor impact is expressed through the visitor spends that amounted to 205.9 billion dinars $(7.0 \%$ of total exports). The sector characteristics show that $86 \%$ of total spending refers to leisure spending, while $14 \%$ is caused by business spending. If attention direct to spending by domestic or foreign tourists in 2019 , the data confirm that $31 \%$ of spending refers to domestic spending and $69 \%$ to foreign spending (World Travel \& Tourism Council, 2020b).

The health crisis caused by the coronavirus has interrupted the growing trend of tourist activities in Serbia, as well as in regions around the world. The first significant decrease in the number of domestic and foreign tourists, as well as the number of overnight stays, was recorded in March of 2020 when the first cases of the virus were registered and the Government made the decision to introduce a state of emergency. Table 4 shows the number of arrivals and overnight stays of domestic and foreign tourists during the period January-September 2020.

Table 4. Number of tourist arrivals and overnight stays (thousands)

\begin{tabular}{|l|r|r|r|r|r|r|}
\hline $\mathbf{2 0 2 0}$ & \multicolumn{3}{|c|}{ Arrivals } & \multicolumn{3}{c|}{ Overnight stays } \\
\hline Month & \multicolumn{1}{|c|}{ All } & \multicolumn{1}{c|}{ Domestic } & \multicolumn{1}{c|}{ Foreign } & \multicolumn{1}{c|}{ All } & \multicolumn{1}{c|}{ Domestic } & \multicolumn{1}{c|}{ Foreign } \\
\hline January & 220.7 & 174.4 & 46.3 & 689.6 & 393.0 & 296.6 \\
\hline February & 233.0 & 141.6 & 91.4 & 729.7 & 494.0 & 235.7 \\
\hline March & 102.6 & 64.3 & 38.3 & 344.6 & 237.2 & 107.4 \\
\hline April & 6.3 & 5.2 & 1.1 & 41.7 & 29.7 & 12.0 \\
\hline May & 47.7 & 44.1 & 3.6 & 170.7 & 151.9 & 18.8 \\
\hline June & 170.4 & 146.0 & 24.4 & 560.2 & 501.9 & 58.3 \\
\hline July & 193.9 & 169.6 & 24.3 & 737.4 & 670.2 & 67.2 \\
\hline August & 294.3 & 263.7 & 30.6 & 1080.7 & 1000.5 & 80.2 \\
\hline September & 195.6 & 162.2 & 33.4 & 698.1 & 603.9 & 94.2 \\
\hline
\end{tabular}

Source: Authors based on Statistical Office of the Republic of Serbia data, 2020b

Compared to the first two months in 2020, a significant decrease in the number of tourist arrivals and overnight stays was noticed in March. It was expected as a direct implication of the spread of the coronavirus. The worst business performances were recorded in April (6.3 thousand arrivals and only 41.7 thousand tourist nights). But, there was a slight increase in the num- 
ber of tourists and overnight stays in the following months. The latest data from the Statistical Office of the Republic of Serbia show that the number of participants in tourism decreased by 43.3\% in September 2020 compared to the same period in 2019. At the same time, the number of overnight stays declined by 22.9\% (Statistical Office of the Republic of Serbia, 2020c).

The percentage changes in the number of international tourists' arrivals are shown in figure 6 . These changes refer to the period January-July of 2020. The negative rates have been recorded since the end of the first quarter and ranged from $-65.8 \%$ in March to $-99.2 \%$ in April.

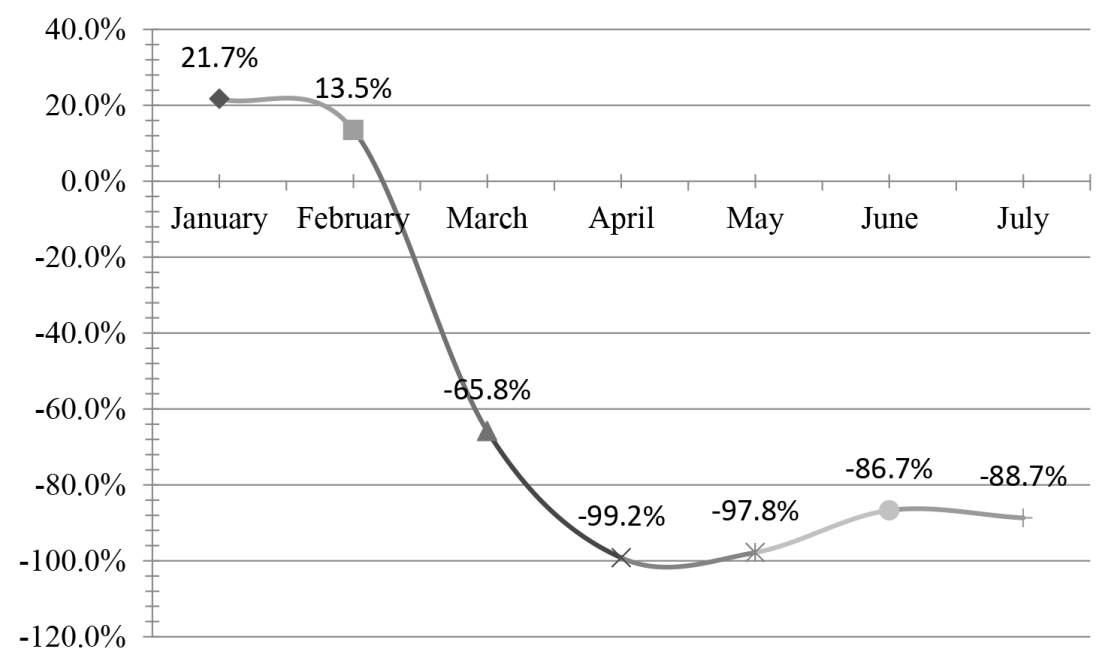

Figure 6. Percentage monthly changes of international arrivals in 2020/2019

Source: Authors based on World Tourism Organization data, 2020a

Even before the health crisis, domestic tourism grew faster than international tourism. The closure of the borders of a great number of world tourist countries, as well as the fear for personal and family safety, are the reasons why a significant number opted for domestic tourist destinations. Cross-border travels have been reduced and domestic tourism is becoming an alternative to travel abroad. Domestic tourism occupies a dominant share in the structure of total tourist arrivals and the number of overnight stays. A great number of domestic tourists was noticed in August 2020. In August 2020, compared to August 2019, the number of overnight stays of domestic tourists increased by $23.1 \%$, while the number of overnight stays of foreign tourists was by $83.7 \%$ lower (Statistical Office of the Republic of Serbia, 2020d) The latest data for September 2020 show that overnight stays of domestic travelers were by $18.8 \%$ greater, while the number of nights of tourists from other countries declined by $76.3 \%$ (Statistical Office of the Republic of Serbia, 2020c).

\section{MEASURES FOR SUPPORTING TOURISM RECOVERY}

The coronavirus pandemic poses enormous economic challenges. The economic impact of domestic containment measures has been compounded by external shocks such as lower commodity prices, depressed demand for exports across the board and disruptions to value chain linkages, as well as a collapse in tourism (EBRD, 2020).

The outbreak of an actual health crisis has impacted countries at different times and in different ways. The most common response to repress the COVID-19 pandemic was the shutdown of borders and travel restrictions. Most countries have responded quickly and strongly and their 
governments adopted widespread measures stepping up over time (World Tourism Organization, 2020b). Across all regions, countries begin to apply measures to restart tourism activities and promote domestic tourism.

World Tourist Organization established the online dashboard covering 220 countries and territories and more than 30 international and regional institutions. $76 \%$ of the total number of covered countries and regions reported some measures to mitigate the effects of the COVID-19, as well as to support a sector recovery. Fiscal and monetary policies are the most popular in all regions, which is confirmed by the data - that 144 countries $(65 \%)$ have adopted packages of fiscal and monetary measures (World Tourism Organization, 2020b). The widespread measures as a swift and strong response by governments around the world to the impact of coronavirus pandemic are shown in table 5.

Table 5. Main adopted measures to mitigate the effects of the crisis

\begin{tabular}{|l|l|}
\hline \multicolumn{2}{|c|}{ Special measures } \\
\hline Fiscal & $\begin{array}{l}\text { Exemption, deferrals, and reduction of VAT and income tax } \\
\text { Economic assistance for SMEs } \\
\text { Investment programs }\end{array}$ \\
\hline Jonetary & $\begin{array}{l}\text { New credit schemes } \\
\text { Moratoria on loans } \\
\text { Facilitate access to credit and finance } \\
\text { Incentive program granted to airlines }\end{array}$ \\
\hline Wabs and skills & $\begin{array}{l}\text { Wirect subsidies to business entities } \\
\text { Reduction or deferral of contributions' payments } \\
\text { Retraining and reskilling tourism workers }\end{array}$ \\
\hline
\end{tabular}

Source: Authors adopted from World Tourism Organization data, 2020b

The governments of a great number of countries in the world reacted quickly by introducing various fiscal measures such as exemption, deferrals and reduction of VAT and income tax, economic assistance, especially for SMEs and entrepreneurs, as well as investment programs. Fiscal stimulus packages are targeting the most impacted sectors and aiming at mitigating the immediate effects of the COVID-19. Monetary measures support tourism directly through new credit schemes, moratoria on loans and facilitate access to credit and finance. All programs aim to provide financial support to business entities and create good preconditions for sector liquidity. The different inventive programs granted to airlines are included in the group of monetary stimulus packages.

Packages are provided to sustain jobs, income and livelihoods related to wages subsidies, direct subsidies to business entities, as well as reduction or deferral of contributions' payments. In order to protect tourism workers and ensure employment retention, most countries especially adopted special measures, such as training and skills development, assisting tourism businesses digital transformation, as well as retraining and reskilling tourism workers (World Tourism Organization, 2020b).

In addition to the above, countries around the world are implementing specific measures that aim to accelerate recovery and help the tourism sector emerge stronger from the current health crisis. Some of them include the vouchers for trips canceled due to pandemics or amendments to laws to protect both customers and tour-operators. The establishment of health and safety protocols in tourist objects is extremely important due to the gradual return of trust in the tourism sector. 
Although countries often focus on international tourism turnover and inflows on that basis, it should be kept in mind that domestic tourism can significantly contribute to generating employment and national economic growth. In the current circumstances, countries around the world have recognized the importance of domestic tourism and launched campaigns for their promotion, as well as adopted specific measures in aim to stimulate domestic tourism demand. The most common measures refer to provide vouchers as an incentive for citizens to spend their holidays in domestic destinations, as well as product development initiatives.

Because the tourism economy has been heavily hit by the COVID-19 pandemic, countries introduce different measures to support the tourism sector and tourism recovery measures. OECD (2020) notices that revised scenarios indicate that the potential shock could range between a 60 $80 \%$ decline in the international tourism economy in 2020 , depending on the duration of the crisis.

The Government of the Republic of Serbia has adopted the Program of financial support to economic entities for maintaining liquidity and working capital in difficult economic conditions caused by the coronavirus. The aim of this action is the regular settlement of obligations to business partners, employees and the state. The special credit conditions have been established for business entities whose predominant activity is in the field of tourism, catering and passenger transport. The program is implemented through the Development Fund of the Republic of Serbia until the funds from the program are spent, not later than December 10, 2020 (Development Fund RS, 2020).

Also, the Government has adopted a program of subsidies to support the hotel industry activities due to business difficulties caused by the COVID-19 pandemic. The aim is to preserve the hotel industry and the employees in that sector. Subsidies are a significant instrument of horizontal state assistance (Vukelić et al., 2014, p. 681). The Ministry of Trade, Tourism and Telecommunications has announced a public call for 350 euro subsidies per individual bed and 150 euros per accommodation unit. Categorized privately owned hotels are entitled to subsidies if they are not subject to the bankruptcy process, financial restructuring, or liquidation proceedings. According to the publicly available data by the Ministry, 312 hotels received subsidies (Ministry of Trade, Tourism and Telecommunications, 2020).

In order to protect travelers, a Regulation on Offering a Replacement Trip from 2020 was passed that regulates the alternate trip for unrealized tourist travel due to the health crisis caused by the pandemic. All customers who have fully or partially paid for the trip by March 15, 2020, have a right to alternate travel. The replacement trip can be realized within one year from the offer delivery and no later than by the end of 2021. In addition to vouchers for replacement trips, tourist vouchers issued by the Ministry of Trade, Tourism and Telecommunications represent a very important and specific measure that aims to improve domestic tourism, as well as an incentive for Serbian citizens to check their vacation at domestic destinations.

\section{FUTURE RESEARCH DIRECTIONS}

The current health crisis caused huge changes in social and economic activities all around the world, resulting in bad financial performances in those sectors which were affected the most seriously. At the same time, fears for personal safety have increased. According to the WTO scenarios, the return to the 2019 level in terms of international tourist arrivals would take $2 \frac{1}{2}$ to four years (World Tourism Organization, 2020a). 
The deep impact of the COVID-19 pandemic requires horizontal and vertical cooperation between relevant institutions on local, regional, and global levels. The governments of countries around the world are implementing specific measures that aim to accelerate sector recovery. The time will show which measures were most effective. In order to build sector resilience, it is essential to follow the effects of the implemented measures and elaborate a roadmap to respond to future shocks (World Travel \& Tourism Council, 2020b). The main challenge would be strengthening the tourism sector on a global level. The creators of policies and relevant institutions have a significant task to ensure sector sustainability, prevent the bankruptcy process, and address liquidity shortage. At the same time, it is necessary to protect the health and personal safety, as well as to regain traveler confidence.

\section{CONCLUSION}

The tourism sector plays a significant role in all regions in the world by contributing to GDP and creating jobs. Travel \& Tourism GDP growth outpaced the overall economy GDP growth for nine consecutive years. While the global economy GDP grew by $2.5 \%$, tourism and travel grew significantly more at $3.5 \%$ in 2019 .

Tourism is constantly facing crisis situations in the conditions of global activities. Despite occasional crises, regardless of the factor that caused it, tourism has seen continued expansion and has shown great resilience. Each crisis requires a swift and strong response by governments in order to mitigate the negative impact on tourist destinations, turnover and revenues, as well as the national economy.

However, the health crisis caused by the COVID-19 pandemic abruptly interrupted global tourism development and led to a steep decline in tourism activities and incomes. The tourism sector is one of the hardest-hit sectors, so it must have been at the center of each policy that has the aim of tourism recovery. The key measures related to fiscal relief and financial support to business entities, as well as to promote job retention. At the same time, domestic tourism will likely be a key driver in the recovery of the sector.

\section{ACKNOWLEDGMENT}

The authors acknowledge funding from the Ministry of Education, Science, and Technological Development of the Republic of Serbia.

\section{REFERENCES}

Baranenko, E. \& Stevanović, S. (2013). Strategies for enhancing competitiveness of the economy as a way to ensure faster recovery from the crisis: the experience of the EU and Serbia. In H. Hanić, M. Özer, Z. Grubišić, I. Domazet (Eds.), Thematic Monograph: Post-crisis recovery (pp. 420433). Belgrade: Belgrade Banking Academy.

Development Fund Republic of Serbia (2020). COVID 19 krediti za likvidnost, available on: https:// fondzarazvoj.gov.rs/lat/proizvodi/likvidnost-covid19

EBRD - The European Bank for Reconstruction and Development (2020) The economics of the coronavirus pandemic, available on: https://www.ebrd.com/what-we-do/coronavirus/economics

Ivanović, O. M., Đeri, L., Stamenković, P., \& Ilić, A. (2020). The Necessity of Using Social Networks in Contemporary Tourism Industry and the Tourist Organization of Serbia. Economic Analysis, 53(1), 94-104. 
Marinković, G. (2018). The quality of financial reporting as a precondition for development global tourist industry. In V. Bevanda \& S. Štetić (Eds.), 3rd International Thematic Monograph: Modern Management Tools and Economy of Tourism Sector in Present Era (pp. 383-392). Belgrade: Association of Economists and Managers of the Balkans with Faculty of Tourism and Hospitality, Ohrid, North Macedonia https://oi.org/10.31410/tmt.2018.383

Marinković, G. (2019). Konvergencija finansijskog izveštavanja u globalnom okruženju. National Monograph (pp. 1-146). Belgrade: Belgrade Banking Academy - Faculty for Banking, Insurance and Finance

Marjanović, D. \& Đukić, M. (2020). Ekonomske mere za ublažavanje posledica COVID-19. In D. Marjanović \& P. Mitić (Eds.), Black Swan in the World Economy 2020 (pp. 91-105). Belgrade: Institute of Economic Sciences.

Milićević, S. \& Ervaćanin, V. (2016). Uticaj kriza na razvoj turizma u svetu. Turističko poslovanje, $18,51-63$

Ministry of Trade, Tourism and Telecommunications (2020). Business entities in the hotel industry in Serbia that are subsidised, https://www.trezor.gov.rs/sr/news/2020_10_09/

Ministry of Trade, Tourism and Telecommunications, Republic of Serbia (2016). Strategy of the tourism development of Republic of Serbia for period 2016-2025, available on: https://mtt.gov. rs/download/3/TOURISM\%20DEVELOPMENT\%20STRATEGY\%20OF\%20RS\%2020162025.pdf

OECD - The Organisation for Economic Co-operation and Development (2020) Tourism Policy Responses to the coronavirus (COVID-19), available on: https://www.oecd.org/coronavirus/ policy-responses/tourism-policy-responses-to-the-coronavirus-covid-19-6466aa20/

Pavlović, D., Bodroža, D. \& Vukmirović, V. (2020). The Economic Impact of the COVID-19 on the Serbia's Labor Market: Statistics and Facts. Economic Analysis: Applied Research in Emerging Markets, 53(1), 1-13.

Popesku, J. (2016). Menadžment turističke destinacije, Belgrade: Singidunum University

Regulation on Sector Classification - Uredba o klasifikaciji delatnosti, Službeni glasnik Republike Srbije, $54 / 2010$

Regulation on the Offer of a Replacement Trip for a Tourist Trip Cancelled or Not Realized Due to COVID-19 Disease Caused by the SARS-CoV-2 virus - Uredba o ponudi zamenskog putovanja za turističko putovanje koje je otkazano ili nije realizovano usled bolesti COVID-19 izazvane virusom SARS-CoV-2, Službeni glasnik Republike Srbije, 63/2020

Serbian Business Registers Agency (2016). Financial Statements Annual Bulletin 2015, available on: https://www.apr.gov.rs/upload/Portals/0/GFI\%202015/Bilten\%202016.pdf

Serbian Business Registers Agency (2017). Financial Statements Annual Bulletin 2016, available on: https://www.apr.gov.rs/upload/Portals/0/GFI\%202015/Bilten\%202017.pdf

Serbian Business Registers Agency (2018). Financial Statements Annual Bulletin 2017, available on: https://www.apr.gov.rs/upload/Portals/0/GFI\%202018/Bilten2017.pdf

Serbian Business Registers Agency (2019). Financial Statements Annual Bulletin 2018, available on: https://www.apr.gov.rs/upload/documents/Bilten\%202019.pdf

Serbian Business Registers Agency (2020). Financial Statements Annual Bulletin 2019, available on: https://www.apr.gov.rs/upload/Portals/0/GFI_2020/Bilten/Bilten2020.pdf

Statistical Offices of the Republic of Serbia (2011). Statistical Yearbook of Serbia, available on: https://publikacije.stat.gov.rs/G2011/Pdf/G20112004.pdf

Statistical Offices of the Republic of Serbia (2020a). Statistical Yearbook of Serbia, available on: https://publikacije.stat.gov.rs/G2020/PdfE/G20202053.pdf

Statistical Offices of the Republic of Serbia (2020b). Monthly Statistical Bulletin - 08/2020, available on: https://publikacije.stat.gov.rs/G2020/Pdf/G20203011.pdf 
Statistical Offices of the Republic of Serbia (2020c). Tourist turnover - September 2020, available on: https://publikacije.stat.gov.rs/G2020/Pdf/G20201290.pdf

Statistical Offices of the Republic of Serbia (2020d). Tourist turnover - August 2020, available on https://publikacije.stat.gov.rs/G2020/PdfE/G20201264.pdf

Stevanović, S. \& Jovičić, E. (2016). Promene korporativnog institucionalnog okruženja u Srbiji od početka ekonomske krize. In J. Minović, D. Bodroža, I. Stošić, B. Drašković (Eds.) Thematic Monograph: Pravci strukturnih promena u procesu pristupanja Evropskoj uniji (pp. 375-392). Belgrade: Institute of Economic Sciences.

Stevanović, S. (2015). Finansijsko strukturne promene privrede Srbije i zaštita poverilaca u periodu finansijske krize. In I. Stošić, M. Malović \& D. Filimonović (Eds.), Thematic Monograph: Strukturne promene u Srbiji-dosadašnji rezultati i perspective (pp. 347-361). Belgrade: Institute of Economic Sciences.

Tourism Law, Službeni glasnik Republike Srbije br. 17/2019, available on: https://www.paragraf.rs/ propisi/zakon_o_turizmu.html

Vukelić, G., Stevanović, S., \& Belopavlović, G. (2014). Analiza finansijske sigurnosti preduzeća u restrukturiranju-prerađivačka industrija. In B. Drašković (Ed.), Thematic Monograph: Deindustrijalizacija u Srbiji: mogućnost revitalizacije industrijskog sektora (pp. 673-689). Belgrade: Institute of Economic Sciences.

World Tourism Organization - UNWTO (2010). UNWTO Tourism Highlights, available on: https:// www.e-unwto.org/doi/pdf/10.18111/9789284413720

World Tourism Organization - UNWTO (2011). UNWTO Tourism Highlights, available on: https:// www.e-unwto.org/doi/pdf/10.18111/9789284413935

World Tourism Organization - UNWTO (2012). UNWTO Tourism Highlights, available on: https:// www.e-unwto.org/doi/pdf/10.18111/9789284414666

World Tourism Organization - UNWTO (2016). UNWTO Tourism Highlights, available on: https:// www.e-unwto.org/doi/pdf/10.18111/9789284418145

World Tourism Organization - UNWTO (2019). International Tourism Highlights, available on: https://www.e-unwto.org/doi/pdf/10.18111/9789284421152

World Tourism Organization (2020b). How are countries supporting tourism recovery?, available on: https://www.e-unwto.org/doi/epdf/10.18111/9789284421893

World Tourism Organization -UNWTO (2020a). World Tourism Barometer, Volume 18, available on: https://www.e-unwto.org/doi/epdf/10.18111/wtobarometereng.2020.18.1.6

World Travel \& Tourism Council - WTTC (2019). Global Economic Impact \& Trends 2019, available on: https://wttc.org/Research/Economic-Impact

World Travel \& Tourism Council - WTTC (2020a). Global Economic Impact \& Trends 2020, available on: https://wttc.org/Research/Economic-Impact

World Travel \& Tourism Council - WTTC (2020b). Serbia - 2020 Annual Research: Key Highlights, available on: https://wttc.org/Research/Economic-Impact 
